\title{
Study of Therapeutic Response on Variable Levothyroxine Supplementation in Hypothyroidism
}

\author{
Dr Avinash Shankar', Dr Amresh Shankar², Dr Anuradha Shankar ${ }^{3}$ \\ ${ }^{1} \mathrm{MBBS}(\mathrm{MGIMS}) ; \mathrm{MD}$ (Internal Medicine);DNB(E\&M);PhD, Post graduate in Endocrinology \& Metabolism \\ (AIIMS-Delhi), Chairman, National Institute of Health \& Research, Institute of Applied Endocrinology, \\ Warisaliganj (Nawada) Bihar, India \\ ${ }^{2}$ BAMS (BRABU); MHA, Centre for Endocrinology \& Metabolism, Aarogyam Punarjeevan, Ram Bhawan, Ara \\ Garden Road, Jagdeo path, Baily Road, Patna 14 \\ ${ }^{3}$ BAMS (BRABU), Director, Centre for Indigenous Medicine \& Research, Warisaliganj(Nawada), Bihar, India
}

*Corresponding Author: Dr Avinash Shankar, MBBS(MGIMS);MD(Internal Medicine);DNB (E\&M); PhD, Post graduate in Endocrinology \& Metabolism(AIIMS-Delhi), Chairman, National Institute of Health \& Research, Institute of Applied Endocrinology, Warisaliganj(Nawada) Bihar, India

\begin{abstract}
Hypothyroidism is increasing worldwide and female predominate male i.e. - 1 out of 50 female and 1 out of 1000 male. TSH (thyroid stimulating Hormone, a secretion of pituitary gland) level is adjudged as an index of diagnosis of thyroid function. Hypothyroid status needs L thyroxin supplementation but its variable schedule poses metabolic dysfunction
\end{abstract}

Objective of Study:

To adjudge clinical effect of early morning fixed time intake of L thyroxin verses unscheduled administration in bioregulation of TSH level and metabolic process

\section{Material \& Methods:}

1000 patients presenting with features suggestive of thyroid hypo function attending at Centre For Endocrinal \& Metabolic research, Aarogyam Punarjeevan, Ram Bhawan, Ara Garden,Patna 14 and Institute of applied Endocrinology, National Institute of Health \& Research, Warisaliganj(Nawada) Bihar 805130 were selected for the proposed study. For the comparative study patients were classified in two groups comprising equal number of patients and one group is administered Lthyroxin early morning at fixed time as first intake while other group at varied time. Both group were recommended L thyroxin and other adjuvant as per their need

Result:

Present study of Levothyroxine supplementation at fixed schedule at early morning prior to onset of body biokinetics ensured excellent therapeutic outcome with TSH bioregulation and better quality of life and sustained and progressive therapeutic response without any adversity.

\section{Conclusion:}

Early morning intake of L thyroxin at fixed time as first intake is worth practicing for optimal thyro regulation and clinical outcome.

Keywor ds: L-thyroxine, biokinetics, fixed schedule

\section{INTRODUCTION}

Hypothyroidism progressively increasing globally in spite of W.H.O caution and measures to restrict Iodine deficiency and estimates burden of 42 millions population in India which is considered due to increasing dietary non nutrients and changed life style. Dietary non nutrients alter iodination of tyrosine and $\mathrm{C}$ cells of thyroid suppressing calcium metabolism resulting in deficiency of ionic form of calcium, accumulation of free radicals, thus presents with manifestations of thyroid hypofunction and hypocalcaemia. ${ }^{1-5}$ 
Thus patients of hypothyroidism, L- thyroxine supplementation is a prime need and its administration schedule poses varied clinical outcome, as in cases though TSH level gets declined but clinical presentation become worse thus patients taking Levothyroxine supplementation been evaluated to adjudge the clinical outcome and quality of life with fixed time early morning dose and varied time schedule ${ }^{6-7}$

Alteration in thyroid function is common among female and hypothyroidism a common presentation among women these days. Hypothyroidism suppresses BMR through its effect on decline in gonadal hormone specially estrogenic and testosterone which causes sub cutaneous accumulation of mucin and retention of water and electrolyte and presents with - myxoedema, asthenia, leg cramps, exertional dyspnoea constipation etc, in addition also suppress sexual function and menses. ${ }^{8-9}$

The most common parameters of ascertaining is assessment of serum thyroxin(T4) and thyroid stimulating hormone (TSH)and therapeutic supplement used is Levothyroxine but unawareness or incomplete education regarding schedule of levothyroxine supplementation, patients consume this supplements with variability ${ }^{10-17}$ i.e.-

- Early in the morning at fixed time as first oral intake

- In the morning after natural routine practice

- Daily after breakfast

- Daily as per convenience

Though TSH gets improved with thyroxin level but patients present with varied presentations i.e.-

- Increase in body weight

- Fatiguability

- Asthenia

- Sleepy

- Abnormal muscular growth

Thus considering the above presentation a clinical assessment of these patients been planned to asses the rationale and significance of early morning fixed time as first consumption of levothyroxine been assessed.

Design of the Study: Comparative clinical study

Objective of the Study: Clinical evaluation of Levothyroxine administration in early morning at fixed time as first consumption verses other dose schedule in securing cure and ensure safety and better quality of life

\section{MATERIAL AND METHODS}

\subsection{Material}

1000 patients of hypothyroidism attending RA. Hospital \& Resaearch Centre Warisaliganj and AArogyam punarjeev, Patna 14 been selected for the proposed study to adjudge the clinical significance and quality of life.

\subsection{Methods}

Selected patients irrespective of their disease status were interrogated for their disease duration, type of therapeutic consumption, their clinical effect, present status, history of consumption of Levothyroxine suppliments, their dose. After clinical examination patients were assessed for their thyroid profile, body weight, blood pressure, blood sugar, hepatic, hematological and renal profile, lipid profile, serum calcium, vitamin D3 and ECG. In patients of hypertension, history of convulsion or unconsciousness.

Based on the clinical presentation and thyroid profile patients were classified as ${ }^{18-21}$ 


\begin{tabular}{|ll|}
\hline \multirow{3}{*}{ Mild } & \\
& Patients presenting with heaviness in the body, exertional dys pnoea \\
& ,lassitude,asthenia,s welling of the body, weight gain,constipation, menstrual \\
& irregularity \\
& TSH level $>5.5-20.5$ \\
Moderate & Above presentation, leg cramps, uneasiness, vertigo, bodyache,joint pain \\
& TSH >20.5-40.5 \\
Severe & With above presentation,obese, unable to walk, recurrent unconsciousness \\
& Involuntary movement \\
& TSH >40.5- 60.5 \\
Malignant & Above presentation \\
& TSH $>60.5$, decreased Vitamin D3 (Cholecalciferol) , Decreased Serum Calcium \\
& ,Raised blood sugar \\
\end{tabular}

For ease of study patients were categorised in two groups and administered i.e.-

Group A: those who were taking levothyroxine supplementation in early morning at fixed time

Group B: Those who were taking levo thyroxin supplementation at variable time daily

Starting dose of L thyroxin:

Following facts must be considered during recommendation of $L$ thyroxin dose, i.e.-

- Patient's age ( In elderly patient start with low dose and titrate the dose slowly)

- Body weight ( $1.5 \mathrm{ug} / \mathrm{Kg} \mathrm{IBW})$

- Cardiovascular status (In patients with coronary insufficiency start with very low dose )

- General health

- Concomittent medication

- Severity and duration of hypothyroidism

Patients were clinically evaluated for weight loss, improvement in vigor and vitality, regression in edema and muscle stiffness, relief in leg cramps and asthenia, serum TSH level.

Patients were investigated for basic bio parameters and based on clinical improvement, quality of life and thyroid profile, therapeutic outcome been classified as -

\begin{tabular}{|ll|}
\hline Excellent : & $\begin{array}{l}\text { Complete reversal of clinical presentation with attainment of ideal } \\
\text { body weight and TSH bioregulation within normal range. } \\
\text { improvement in clinical presentation ,decline in body weight and TSH } \\
\text { level } \\
\text { Only decline in TSH level without clinical relief and decline in body } \\
\text { weight }\end{array}$ \\
\hline
\end{tabular}

\section{OBS ERVATION}

Majority 297 (29.7\%) were of age group 25-30 years while 68(6.8\%) and 37(3.7\%) were of age group 15-20 years and 45-50 years respectively (T-1)

Out of all 5\% cases were male and 95\% female (Pie diagram showing male: female composition)

Out of all 131(13.1\%) patients were with TSH > 50.5 while 27(2.7\%) were with TSH 5.5-10.5 (T-2)

Among the selected patients 199 were of mild, 427 moderate, 243 severe and 131 malignant grade of severity (Bar diagram)

Considering the body weight $239(23.9 \%)$ were with body weight $75-80 \mathrm{Kg}(>\mathrm{IBW})$ while $105(10.5 \%)$ were having body weight $>100 \mathrm{~kg}$ and 212(21.2\%) with body weight $70-75 \mathrm{~kg}$ (T-3)

Among selected patients $66.2 \%$ patients were with haemoglobin $>10 \mathrm{gm} \%, 5 \%$ were with SGOT and SGPT >30 IU, 99.9\% posses normal renal profile though $2.4 \%$ shows presence of albumin, $0.2 \%$ 
presence of RBC and $64.2 \%$ presence of calcium oxalate sand in urine, $99.6 \%$ were with normal serum cholesterol, $37.6 \%$ with low Vitamin D3 and 39\% with low serum calcium.

Out of all patients taking L- thyroxin supplementation at early morning at fixed time (group A) were 467 and 533 were taking L- thyroxin supplementation at unscheduled manner daily (group B). Group A constitutes no male patients.

Patients of group A shows sustained and progressive decline in TSH level in all while patients of group B shows variable and mild decline in TSH level.

97.6\% patients of group A had marked relief in clinical presentation while only $63.4 \%$ of group B, 99.6\% of group A patients had progressive decline in body weight and attended Ideal body weight without any discomfort while only $21.2 \%$ of group B had declined in body weight but non attended ideal body weight for the age and height and $35.8 \%$ patients of group B had abnormal muscle mass growth.

$87.6 \%$ patients of group A had blood pressure bioregulation while $62.7 \%$ patients of group B remained with low blood pressure. $81.8 \%$ of group A had relief of constipation while 20.4 of group B, menses and libido marked improved in $84.8 \%$ and $92.8 \%$ respectively of group A contrary to $5.2 \%$ and $27.4 \%$ respectively of group B.

Conclusively $97.6 \%$ of group A achieved grade I therapeutic outcome as against 7\% of group B (T-)

\section{Dis CUSSION}

Thyroid secretes hormone to bio regulate body metabolism and its under activity is termed as hypothyroidism i.e.- persons suffering with hypothyroidism presents with manifestation of slow metabolism. Approximately one in 50 women and 1 in 1000 men suffers with hypothyroidism in their life and TSH (Thyroid stimulating Hormone, secreted by Pituitary gland) level is a most sensitive index, as elevated TSH level always suggest under activity of thyroid. ${ }^{22-28}$

Though various dose schedule been clinically evaluated but early morning fixed time consumption through out life remain worth as it ensure sustained and progressive decline in TSH level, marked relief of clinical presentation, decline in body weight, normotensive state and grade I clinical out come with improved quality of life in $97 \%$ patient while other schedules fail to ensure even symptomatic relief though causes decline in TSH level. This clinical supremacy can be explained as -

Early morning fixed time consumption of Laevo thyroxin acted by oral saliva and salivary amylase effect gets pronounced while consumption after oral ingestion or water intake oral saliva gets washed off or diluted thus administered L thyroxin fails to potentiate salivary amylase and restricted conversion of T4 to T3, hence early morning consumption not only causes decline in TSH but also ensure clinical improvement ${ }^{29-31}$.

L Thyroxin As first intake -- Potentiate Salivary amylase , increased $\mathrm{T}_{4^{-}}>\mathrm{T}_{3}$
After water intake
dilute saliva
fails to act on L thyroxin
decreased conversion of T4-T3
Slows metabolic process body weight,
Fails to relieve presentation


Table1. Distribution of patients as per age and sex

\begin{tabular}{|l|l|l|l|}
\hline $\begin{array}{l}\text { Age group } \\
\text { (In years) }\end{array}$ & \multicolumn{4}{|l|}{ Number of patients } \\
\hline & Male & Female & Total \\
\hline $15-20$ & 02 & 66 & 68 \\
\hline $20-25$ & 07 & 208 & 215 \\
\hline $25-30$ & 09 & 288 & 297 \\
\hline $30-35$ & 11 & 220 & 231 \\
\hline $35-40$ & 06 & 72 & 78 \\
\hline $40-45$ & 07 & 67 & 74 \\
\hline $45-50$ & 08 & 29 & 37 \\
\hline
\end{tabular}

Pie diagram showing Male-Female Composition

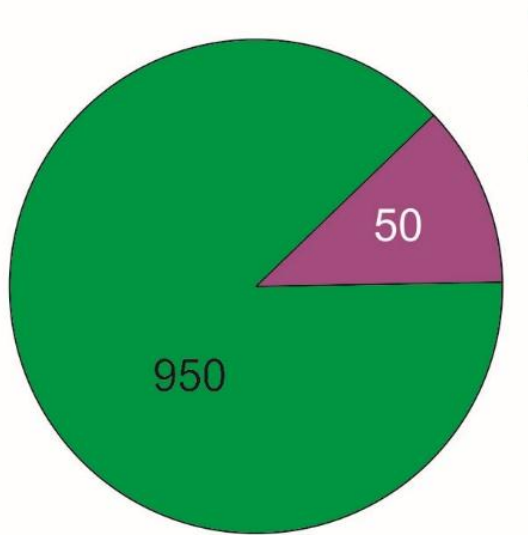

Male

Female

Table2. Distribution of patients as per TSH level

\begin{tabular}{|l|l|}
\hline TSH Level (in $\mu \mathrm{IU} / \mathrm{dl})$ & Number of patients \\
\hline $5.5-105$. & 27 \\
\hline $10.5-15.5$ & 68 \\
\hline $15.5-20.5$ & 104 \\
\hline $20.5-25.5$ & 98 \\
\hline $25.5-30.5$ & 129 \\
\hline $30.5-35.5$ & 84 \\
\hline $35.5-40.5$ & 116 \\
\hline $40.5-45.5$ & 139 \\
\hline $45.5-50.5$ & 104 \\
\hline$>50.5$ & 131 \\
\hline
\end{tabular}

\section{Bar diagram showing degree of Severity}

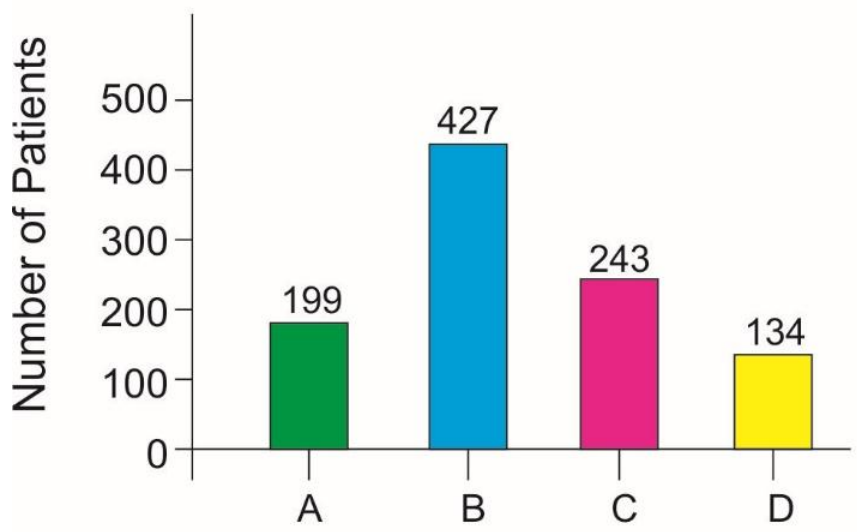

Degree of severity

(Key: $A=$ Mild $; B=$ moderate $C=$ severe and $D=$ malignant $)$ 
Study of Therapeutic Response on Variable Levothyr oxine Supplementation in Hypothyr oi dism

Table3. Distribution of patients as per body weight

\begin{tabular}{|l|l|}
\hline Body weight (in Kg) & Number of patients \\
\hline $70-75$ & 212 \\
\hline $75-80$ & 239 \\
\hline $80-85$ & 121 \\
\hline $85-90$ & 111 \\
\hline $90-95$ & 104 \\
\hline $95-100$ & 108 \\
\hline$>100$ & 105 \\
\hline
\end{tabular}

Table4. Distribution of patients as per basic bio parameters

\begin{tabular}{|c|c|}
\hline Particulars & Number of patients \\
\hline $\begin{array}{l}\text { Haematological : } \\
\text { Haemoglobin : } \\
<10 \text { gm \% } \\
>10 \text { gm\% }\end{array}$ & $\begin{array}{l}338 \\
662\end{array}$ \\
\hline $\begin{array}{l}\text { Hepatic profile : } \\
\text { SGOT : } \\
<30 \mathrm{IU} \\
>30 \mathrm{IU}\end{array}$ & $\begin{array}{l}950 \\
50\end{array}$ \\
\hline $\begin{array}{l}\text { SGPT : } \\
<30 \mathrm{IU} \\
>30 \mathrm{IU}\end{array}$ & $\begin{array}{l}950 \\
50\end{array}$ \\
\hline $\begin{array}{l}\text { Renal profile : } \\
<1.5 \mathrm{mg} \\
>1.5 \mathrm{mg}\end{array}$ & $\begin{array}{l}999 \\
01\end{array}$ \\
\hline $\begin{array}{l}\text { Blood Urea } \\
<26 \mathrm{mg} \\
>26 \mathrm{mg}\end{array}$ & $\begin{array}{l}999 \\
01\end{array}$ \\
\hline $\begin{array}{l}\text { Urine : } \\
\text { Albumin } \\
\text { Present } \\
\text { Absent } \\
\text { RBC } \\
\text { Absent } \\
\text { Present } \\
\text { Oxalate crystal } \\
\text { Present } \\
\text { Absent }\end{array}$ & $\begin{array}{l}24 \\
976 \\
02 \\
998 \\
642 \\
358\end{array}$ \\
\hline $\begin{array}{l}\text { Lipid profile } \\
\text { Total Serum Cholestrol } \\
<200 \mathrm{mg} \\
>200 \mathrm{mg}\end{array}$ & $\begin{array}{l}996 \\
04\end{array}$ \\
\hline $\begin{array}{l}\text { Vitamin D3 (Chole calciferol) } \\
<20 \\
>20\end{array}$ & $\begin{array}{l}376 \\
624\end{array}$ \\
\hline $\begin{array}{l}\text { Serum Calcium : } \\
<8.8 \mathrm{mg} \% \\
>10 \mathrm{mg} \%\end{array}$ & $\begin{array}{l}390 \\
610\end{array}$ \\
\hline
\end{tabular}


Graph showing comparative decline in serum TSH level

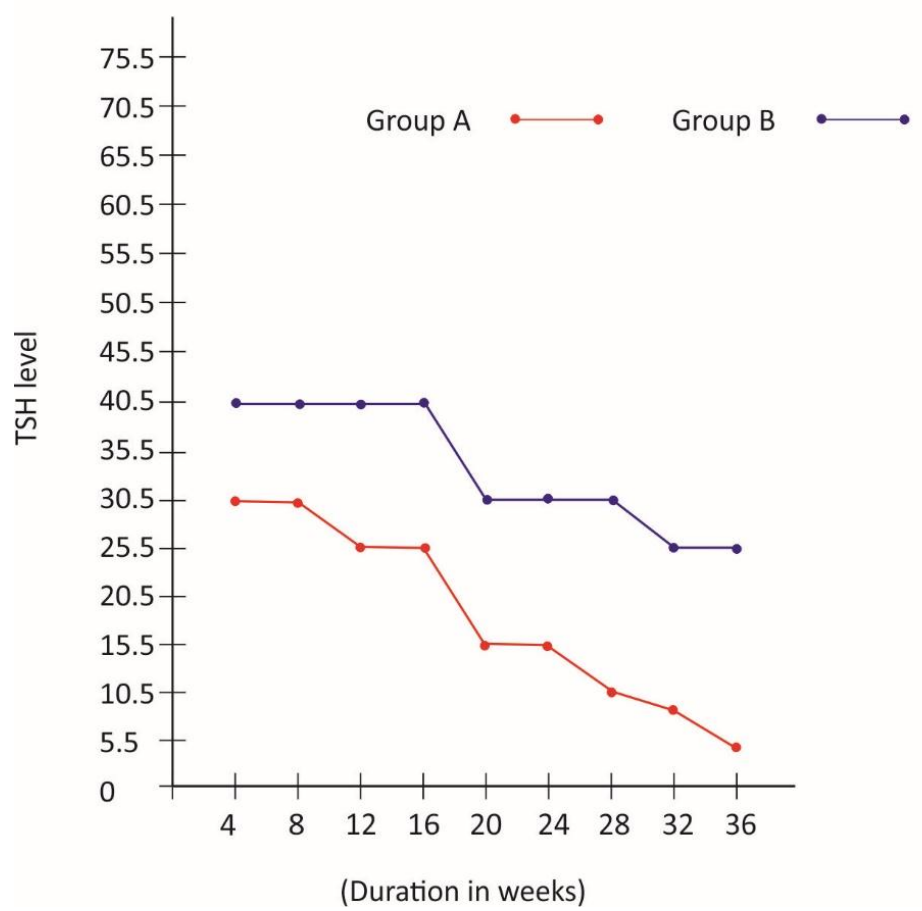

Table5. Shows outcome of therapy

\begin{tabular}{|c|c|c|}
\hline Particulars & Number of 1 & \\
\hline & Group A & Group B \\
\hline Relief of clinical presentation & $488(97.6 \%)$ & $317(63.4 \%)$ \\
\hline $\begin{array}{l}\text { Body weight: } \\
\text { Decline } \\
\text { Unaltered } \\
\text { Abnormal body weight }\end{array}$ & $\begin{array}{l}498(99.6 \%) \\
02 \\
-\end{array}$ & $\begin{array}{l}106(21.2 \%) \\
215(43 \%) \\
179(35.8 \%)\end{array}$ \\
\hline $\begin{array}{l}\text { Blood Pressure: } \\
\text { Normal } \\
\text { Low }\end{array}$ & $\begin{array}{l}438(87.6 \%) \\
62\end{array}$ & $\begin{array}{l}89(17.8 \%) \\
411(62.2 \%)\end{array}$ \\
\hline $\begin{array}{l}\text { Constipation } \\
\text { Relieved } \\
\text { Unaltered }\end{array}$ & $\begin{array}{l}409(81.8 \%) \\
91\end{array}$ & $\begin{array}{l}102 \\
398(79.6 \%)\end{array}$ \\
\hline $\begin{array}{l}\text { Menses } \\
\text { Bioregulated } \\
\text { Unchanged }\end{array}$ & $\begin{array}{l}424(84.8 \%) \\
51\end{array}$ & $\begin{array}{l}31 \\
444(88.8 \%)\end{array}$ \\
\hline $\begin{array}{l}\text { Libido } \\
\text { Decreased } \\
\text { Unchanged }\end{array}$ & $\begin{array}{l}36 \\
464(92.8 \%)\end{array}$ & $\begin{array}{l}313(62.6 \%) \\
187(27.2 \%)\end{array}$ \\
\hline $\begin{array}{l}\text { Therapeutic outcome } \\
\text { Grade I } \\
\text { Grade II } \\
\text { Grade III }\end{array}$ & $\begin{array}{l}97.6 \% \\
2.4 \% \\
-\end{array}$ & $\begin{array}{l}7 \% \\
76 \% \\
17 \%\end{array}$ \\
\hline
\end{tabular}

\section{REFERENCES}

[1] Hollowell JG, Staehling NW, Flanders WD, et al. Serum TSH, T(4), and thyroid antibodies in the United States population (1988 to 1994): National Health and Nutrition Examination Survey (NHANES III) J Clin Endocrinol Metab. 2002; 87 (2):489-499. [PubMed

[2] Vanderpump MP, Tunbridge WM, French JM, et al. The incidence of thyroid disorders in the community: a twenty-year follow-up of the Whickham Survey. Clin Endocrinol (Oxf) 1995; 43(1): 55-68.[PubMed]

[3] Leese GP, Flynn RV, Jung RT, Macdonald TM, Murphy MJ, Morris AD. Increasing prevalence and incidence of thyroid disease in Tayside, Scotland: the Thyroid Epidemiology Audit and Research Study (TEARS) Clin Endocrinol. 2008; 68 (2):311-316. [PubMed]

[4] Avinash Shankar etal ; Hypothyroidism and Ayurveda ,IJCCLM, 3:3:2017(1-9) 
[5] Avinash Shankar etal; An unusual presentation in altered thyroid function in male , BAOJ Med Nursing, an open access journal Volume 4; Issue 2; 0552018

[6] Roberts CG, Ladenson PW. Hypothyroidism. Lancet. 2004; 363 (9411):793-803. [PubMed]

[7] Canaris GJ, Steiner JF, Ridgway EC. Do traditional symptoms of hypothyroidism correlate with biochemical disease? J Gen Intern Med. 1997; 12(9):544-550. [PMC free article] [PubMed]

[8] Jonklaas J, Bianco AC, Bauer AJ, et al. Guidelines for the treatment of hypothyroidism: prepared by the american thyroid as sociation task force on thyroid hormone replacement. Thyroid 2014; 24:1670.

[9] Oppenheimer JH, Braverman LE, Toft A, et al. A therapeutic controversy. Thyroid hormone treatment: when and what? J Clin Endocrinol Metab 1995; 80:2873.

[10] Okosieme OE, Belludi G, Spittle K, Kadiyala R, Richards J. Adequacy of thyroid hormone replacement in a general population. QJM. 2011; 104(5):395-401. [PubMed]

[11] Parle JV, Franklyn JA, Cross KW, Jones SR, Sheppard MC. Thyroxine prescription in the community: serum thyroid stimulating hormone level assays as an indicator of undertreatment or overtreatment. $\mathrm{Br} \mathrm{J}$ Gen Pract. 1993; 43(368):107-109. [PMC free article] [PubMed]

[12] Brabant G, Beck-Peccoz P, Jarzab B, et al. Is there a need to redefine the upper normal limit of TSH? Eur J Endocrinol. 2006; 154(5):633-637. [PubMed]

[13] Lindholm J, Laurberg P. Hypothyroidism and thyroid substitution: historical aspects. J Thyroid Res. 2011; 2011:809341. [PMC free article] [PubMed]

[14] Roos A, Linn-Rasker SP, van Domburg RT, Tijssen JP, Berghout A. The starting dose of levothyroxine in primary hypothyroidism treatment: a prospective, randomized, double-blind trial. Arch Intern Med. 2005; 165(15):1714-1720. [PubMed]

[15] Escobar-Morreale HF, Obregon MJ, Escobar del Rey F, Morreale de Escobar G. Replacement therapy for hypothyroidism with thyroxine alone does not ensure euthyroidism in all tissues, as studied in thyroidectomized rats. J Clin Invest. 1995; 96(6):2828-2838. [PMC free article] [PubMed]

[16] Sawin CT, Herman T, Molitch ME, London MH, Kramer SM. Aging and the thyroid. Decreased requirement for thyroid hormone in older hypothyroid patients. Am J Med. 1983; 75(2):206-209. [PubMed]

[17] Turner MR, Camacho X, Fischer HD, et al. Levothyroxine dose and risk of fractures in older adults: nested case-control study. BMJ. 2011; 342:d2238. [PMC free article] [PubMed]

[18] Pollock MA, Sturrock A, Marshall K, et al. Thyroxine treatment in patients with symptoms of hypothyroidism but thyroid function tests within the reference range: randomised double blind placebo controlled crossover trial. BMJ. 2001; 323(7318):891-895. [PMC free article] [PubMed]

[19] Pollock MA, Sturrock A, Marshall K, et al. Thyroxine treatment in patients with symptoms of hypothyroidism but thyroid function tests within the reference range: randomised double blind placebo controlled crossover trial. BMJ 2001; 323:891.

[20] Fish LH, Schwartz HL, Cavanaugh J, et al. Replacement dose, metabolism, and bioavailability of levothyroxine in the treatment of hypothyroidism. Role of triiodothyronine in pituitary feedback in humans. N Engl J Med 1987; 316:764.

[21] Stagnaro-Green A, Abalovich M, Alexander E, et al. Guidelines of the American thyroid association for the diagnosis and management of thyroid disease during pregnancy and postpartum. Thyroid. 2011; 21(10):1081-1125. [PMC free article] [PubMed]

[22] Bolk N, Visser TJ, Kalsbeek A, van Domburg RT, Berghout A. Effects of evening vs morning thyroxine ingestion on serum thyroid hormone profiles in hypothyroid patients. Clin Endocrinol. 2007; 66(1):4348. [PubMed]

[23] Bolk N, Visser TJ, Nijman J, Jongste IJ, Tijssen JG, Berghout A. Effects of evening vs morning levothyroxine intake: a randomized double-blind crossover trial. Arch Intern Med. 2010; 170(22):19962003. [PubMed]

[24] Elliott DP. Effect of levothyroxine administration time on serum TSH in elderly patients. Ann Pharmacother. 2001; 35(5):529-532. [PubMed]

[25] Bach-Huynh TG, Nayak B, Loh J, Soldin S, Jonklaas J. Timing of levothyroxine administration affects serum thyrotropin concentration. J Clin Endocrinol Metab. 2009; 94(10):3905-3912. [PMC free article][PubMed]

[26] Walsh JP, Ward LC, Burke V, et al. Small changes in thyroxine dosage do not produce measurable changes in hypothyroid symptoms, well-being, or quality of life: results of a double-blind, randomized clinical trial. J Clin Endocrinol Metab. 2006; 91(7):2624-2630. [PubMed]

[27] Gullo D, Latina A, Frasca F, Le Moli R, Pellegriti G, Vigneri R. Levothyroxine monotherapy cannot guarantee euthyroidism in all athyreotic patients. PLoS One. 2011; 6(8):e22552. [PMC free article][PubMed] 
[28] Waise A, Price HC. The upper limit of the reference range for thyroid-stimulating hormone should not be confused with a cut-off to define subclinical hypothyroidism. Ann Clin Biochem 2009; 46:93.

[29] Bolk N, Visser TJ, Nijman J, et al. Effects of evening vs morning levothyroxine intake: a randomized doubleblind crossover trial. Arch Intern Med 2010; 170:1996.

[30] Gordon MB, Gordon MS. Variations in adequate levothyroxine replacement therapy in patients with different causes of hypothyroidism. Endocr Pract 1999; 5:233.

[31] Gullo D, Latina A, Frasca F, et al. Levothyroxine monotherapy cannot guarantee euthyroidism in all athyreotic patients. PLoS One 2011; 6:e22552.

Citation: A. Shankar et al., "Study of Therapeutic Response on Variable Levothyroxine Supplementation in Hypothyroidism", International Journal of Clinical Chemistry and Laboratory Medicine (IJCCLM), vol. 4, no. 2, pp. 26-34, 2018. http://dx.doi.org/10.20431/2455-7153.0402005

Copyright: () 2018 Authors. This is an open-access article distributed under the terms of the Creative Commons Attribution License, which permits unrestricted use, distribution, and reproduction in any medium, provided the original author and source are credited. 